\title{
Occurrence of Paratanaisia spp. Freitas, 1951 in a domiciled cockatiel (Nymphicus hollandicus, Psittaciformes: Cacatuidae)
}

\author{
Ocorrência de Paratanaisia spp. Freitas, 1951 em calopsita (Nymphicus hollandicus, \\ Psittaciformes: Cacatuidae) domiciliada
}

Mariele De Santi ${ }^{1 *}$; Caroline do Couto ${ }^{1}$; Karin Werther ${ }^{2}$

\begin{abstract}
'Serviço de Medicina de Animais Selvagens, Hospital Veterinário "Governador Laudo Natel”, Faculdade de Ciências Agrárias e Veterinárias, Universidade Estadual Paulista - UNESP, Jaboticabal, SP, Brasil

${ }^{2}$ Laboratório de Patologia de Animais Selvagens, Departamento de Patologia Veterinária, Faculdade de Ciências Agrárias e Veterinárias, Universidade Estadual Paulista - UNESP, Jaboticabal, SP, Brasil
\end{abstract}

Received February 15, 2018

Accepted April 03, 2018

\begin{abstract}
Digenetic eucotylids of the Paratanaisia genus are widely reported parasites of the avian renal system. The infection, commonly reported in free-living and zoo-housed birds, is described for the first time in a domiciled bird, a cockatiel kept as pet bird with free access to the yard outdoors. The bird was received at Veterinary Hospital, where clinical and radiographic evaluations suggested a case of heavy-metal poisoning. Although the bird received supportive care and a chelating agent, it died the next day. The necropsy showed friable kidneys and congestion of blood vessels in structures such as the skin, proventriculus, brain, and skullcap. The histopathological evaluation of the kidneys revealed multifocal hemorrhages, commonly found in cases of heavy-metal poisoning. Parasitic structures similar to those of the digenean trematodes Paratanaisia spp. were also observed inside dilated collecting ducts, which presented epithelial cell flattening and vacuolization. There was compression of adjacent tissue and discrete fibrotic areas. In the presence of intermediate hosts in the yard, the synanthropic nature of some wild free-living birds could make them a source of trematodes infection and dissemination for pet birds. Conversely, the infected cockatiel could also have served as a reservoir and carrier of trematodes to wild free-living birds.
\end{abstract}

Keywords: Cockatiel, kidneys, histopathology, trematodes, Eucotylidae.

\section{Resumo}

Eucotilídeos digenéticos do gênero Paratanaisia são amplamente descritos como parasitas do trato urinário de aves. A infecção, comumente relatada em aves de vida livre e em zoológicos, é descrita pela primeira vez em uma ave domiciliada, uma calopsita mantida como ave de companhia com livre acesso ao jardim externo. A ave foi recebida no Hospital Veterinário onde avaliaçôes clínicas e radiográficas sugeriram um quadro de intoxicação por metal pesado. Embora tenha recebido tratamento de suporte e agente quelante a ave veio a óbito no dia seguinte. A necropsia demonstrou rins de consistência friável e congestáo dos vasos sanguíneos da pele, proventrículo, cérebro e calota craniana. A avaliaçáo histopatológica dos rins revelou hemorragias multifocais comumente observadas em intoxicação por metais pesados. Estruturas parasitárias similares àquelas observadas em Paratanaisia spp. foram observadas no interior de ductos coletores dilatados, os quais apresentavam achatamento e vacuolização de células epiteliais. Havia compressáo do tecido adjacente e discretas áreas de fibrose. Na presença de hospedeiros intermediários no jardim, a condição sinantrópica de algumas aves de vida livre poderia torná-las fonte de infecção e disseminação de trematódeos para aves domiciliadas. Em contrapartida, a calopsita infectada poderia também servir como reservatório e carreador de trematódeos para aves de vida livre.

Palavras-chave: Calopsita, rins, histopatologia, trematódeos, Eucotylidae.

The cockatiel (Nymphicus hollandicus) is in the order Psittaciformes of the Cacatuidae family. All Psittaciformes are extremely popular due to their beauty, intelligence, and sociable

*Corresponding author: Mariele De Santi. Faculdade de Ciências Agrárias e Veterinárias, Universidade Estadual Paulista - UNESP, Via de Acesso Prof. Paulo Donato Castellane, s/n, Bairro Rural, CEP 14884-900, Jaboticabal, SP, Brasil. e-mail: mariele.santi@gmail.com nature, which makes them the birds most frequently kept as pets (GRESPAN \& RASO, 2014). However, inadequate management and facilities may allow the introduction of pathogens that can lead to different clinical manifestations varying from benign to acute death (GREINER \& RITCHIE, 1994).

Eucotylidae digeneans of the Paratanaisia genus (Santos, 1934) Freitas 1959, in the family Eucotylidae Cohn, 1904 and subfamily 
Tanaisiinae Freitas (KANEV et al., 2002), are parasites of the avian renal system. These trematodes have been reported in a wide range of bird species (GOMES et al., 2005; TAVELA et al., 2014; XAVIER et al., 2015; MOMO et al., 2016; SANTI et al., 2017), testifying to their low definitive host specificity. Infections have been described in both free-living and zoo-housed Psittaciformes, including macaws (Ara ararauna and Propyrrhura maracana), parakeets (Pyrrhura leucotis, Eupsittula aurea, Psittacara leucophthalmus, and Brotogeris chiriri), parrots (Amazona amazonica and Amazona aestiva), and cockatiels (N. hollandicus) (LUPPI et al., 2007; SILVA et al., 2016; SANTI et al., 2018).

Like other digeneans, Paratanaisia have a heteroxenous cycle with gastropod mollusks acting as the intermediate hosts and birds as the definitive hosts. To acquire an infection, the bird must ingest the infective form of the parasite, the metacercariae encysted in the tissues of infected mollusks. The mollusks reported as the intermediate hosts for Paratanaisia in Brazil are the land snails Leptinaria unilamellata (KELLER \& ARAÚJO, 1992) and Subulina octona (BRANDOLINI \& AMATO, 2006), which are very small, 4-5 $\mathrm{mm}$ and $13 \mathrm{~mm}$, respectively (ARAÚJO \& BESSA, 1993; ARAÚJO \& KELLER, 1993). These species are commonly observed in shaded and humid places such as under rock and plant surfaces and in construction cracks (ARAÚJO \& BESSA, 1993).

Macroscopic and histological alterations have been described for natural and experimental infections with variable degrees of impairment (MENEZES et al., 2001; GOMES et al., 2005; ABDO \& SULTAN, 2013; SILVA et al., 2016; SANTI et al., 2017). Enlargement with brown-yellowish discolorations and interstitial lymphoplasmacytic infiltrate have been described in Psittaciformes (LUPPI et al., 2007). Chickens (Gallus gallus) experimentally infected with Paratanaisia bragai had an absence of clinical signs despite multifocal interstitial nephritis and altered epithelial cells. In contrast, some authors have reported an absence of macroscopic alterations despite the presence of parasites
(MENEZES et al., 2001; MAPELI et al., 2003; TAVELA et al., 2014). Therefore, the parasite's role in the development of clinical disease remains uncertain.

This report describes the histopathological alterations associated with a natural Paratanaisia spp. infection in a domiciled cockatiel ( $N$. hollandicus). A seven-year old female cockatiel presented with apathy, hyporexia, and paresis in the right pelvic limb at the Veterinary Hospital "Governador Laudo Natel” in the São Paulo State University (Unesp), School of Agricultural and Veterinarian Sciences, Jaboticabal, Brazil. The owner reported that the bird lived with five other cockatiels, having free access to the home yard, a green place where they used to forage and have contact with free-living birds, such as Passeriformes and Columbiformes. Reported also that four days before, the bird had ingested some pieces of metal from a bracelet. Radiographic exams were performed and the images showed several irregularly shaped structures with metallic radiopacity and poorly defined limits, located at ventricular lumen topography. This observation along with clinical signs (apathy and hyporexia) and the history (ingestion of pieces of metal from a bracelet), strongly suggested a case of heavy-metal poisoning. Although the bird received supportive care and a chelating agent, it died the next day and the necropsy was performed. Specimens were obtained from a range of tissues, fixed in $10 \%$ buffered formalin for $24 \mathrm{~h}$, dehydrated, embedded in paraffin, cut into $4-\mu \mathrm{m}$ sections, and stained with hematoxylin and eosin (HE) for histopathological analysis (JECKEL, 2007). The slides were examined and photographed under an Olympus BX-51 light microscope.

At the post mortem examination, the kidneys showed a friable consistency, and there was congestion of blood vessels in several structures, such as the skin, proventriculus, brain, and skullcap. The histopathological analysis revealed congestion of the sinusoids, discrete multifocal inflammatory infiltrate in the hepatic parenchyma, and in the renal tissue, twelve parasitic structures were observed inside the collecting ducts. These structures displayed
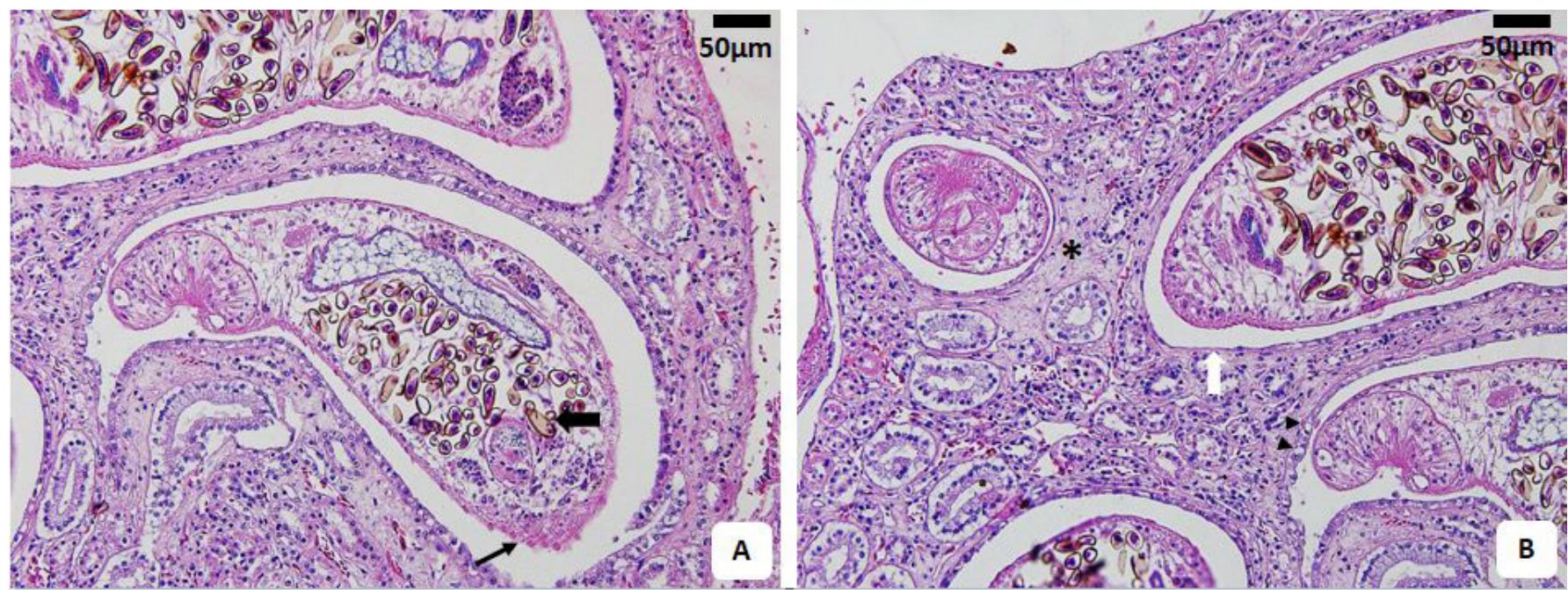

Figure 1. Photomicrographs of cockatiel (Nymphicus hollandicus) kidney tissue. (A) Cross section of the parasite inside collecting ducts showing a parenchyma filled with ellipsoid brownish eggs (large arrow) and a cuticle covering similar to those of the digenean trematodes Paratanaisia spp. (thin arrow). Hematoxylin-eosin stain. Scale bar $=50 \mu \mathrm{m}$; (B) Dilated collecting ducts with flattening (white arrow) and vacuolization (arrowheads) of epithelial cells beside discrete areas of fibrosis (asterisk). Hematoxylin-eosin stain. Scale bar $=50 \mu \mathrm{m}$. 
a parenchyma filled with ellipsoid brownish eggs and a cuticle cover similar to those of the digenean trematodes Paratanaisia spp. (Figure 1a). The parasitized collecting ducts were dilated, with areas of flattened epithelial cells and epithelial cell vacuolization. In addition, there was compression of the adjacent tissue and discrete areas of fibrosis (Figure 1b). Multifocal hemorrhage and discrete perivascular inflammatory infiltrate were also observed, but they were unrelated to the parasitized collecting ducts.

No inflammatory infiltrates were observed near the areas where the parasites were present, which differs from descriptions in other Psittaciformes where infections with Paratanaisia trematodes have resulted in worse impairment (LUPPI et al., 2007; SILVA et al., 2016). The relatively discrete histopathological alterations observed in this case could be related to the low parasitic burden or to a low pathogenicity of the parasite in this bird species; it could even be an indication of recent infection. Unfortunately, it was not possible to determine when the infection was acquired, as the bird had access to the yard its entire life.

Dilated collecting ducts are frequently observed in Paratanaisia infections (ABDO \& SULTAN, 2013; UNWIN et al., 2012; TAVELA et al., 2014; SANTI et al., 2017). The duct enlargement may develop due to the large body size of the parasites, although some authors have suggested it could be a compensatory mechanism to allow urine flow (PINTO et al., 2004). In this case, the enlargement of the parasitized collecting ducts led to the discrete compression of adjacent tissue, with the consequent development of discrete areas of fibrosis. The morphological alterations in the epithelial cells were probably caused by physical compression, as has been previously reported in domestic chicken (XAVIER et al., 2015). There was no relationship between the parasite size and the severity of the lesions, unlike what has been observed in Ara ararauna parasitized by P. bragai (SILVA et al., 2016).

In addition to the descriptions of infection by Paratanaisia in free-living birds, infection has also been described in zoo-housed birds (UNWIN at al., 2012). However, the parasite has never been reported in domiciled birds. In zoo facilities, the enclosures are established to provide more natural environments of vegetation and substrate, which enables the survival of the intermediate hosts. Domiciled birds are commonly kept in internal enclosures, or occasionally free inside the home but without access to the outside, primarily due to the possibility of escape. Because the infection requires the ingestion of metacercariae-infected mollusks in the environment and pet birds are usually maintained indoors, they are unlikely to acquire an infection. The bird in this report, however, had frequent access to the yard of the home, and foraging on grass made the ingestion of metacercariae-infected mollusks possible.

Columbiformes have often been described as hosts for Paratanaisia spp. (UNWIN et al., 2012; XAVIER et al., 2015; SANTI et al., 2018), probably due to their habit of feeding on a wide variety of items such as grains, seeds, insects, and small invertebrates (SICK, 1997). Such feeding habits combined with their synanthropic nature could make them a source of trematodes infection and dissemination. Conversely, the infected cockatiel could also have served as a reservoir and carrier of trematodes to the wild free-living birds commonly found living around the home.

As pet birds are commonly in close contact with their owners and carefully observed on a daily basis, non-specific clinical signs of disease should be better recognized, allowing the birds to be presented for medical evaluation. The bird in this report had never shown any clinical signs of trematodes infection such as the cachexia, apathy, and dehydration observed in macaws infected with Paratanaisia robusta and P. bragai (LUPPI et al., 2007). It was not possible to state how long this bird had been infected by the trematodes, because it had accessed the yard throughout its life. Information about the life span of the parasites inside the definitive hosts are not available, precluding to state if there was a unique infection or continuous recruitment of parasites.

Clinical evaluation and imaging exams, strongly suggested a case of heavy-metal poisoning and the bird probably died as a result of many systemic alterations caused by the poisoning. Once in the bloodstream, heavy-metal causes pansystemic damage, including intravascular hemorrhage and vascular necrosis, besides liver, neuronal and renal damage (DUMONCEAUX \& HARRISON, 1994), some of the alterations observed in this case. The trematode infection was a necropsy finding, though it is relevant to note that avian species attempt to hide signs of disease as a survival adaptation (HARRISON \& RITCHIE, 1994), and sometimes the disease progresses to an advanced stage with no possibility of recovering.

Pet bird owners are not generally knowledgeable about the parasites that can infect their pets or the transmission pathways that can lead to disease in and even the death of birds, a scenario they could avoid by presenting the birds for routine medical evaluation. As important as medical evaluation is the necropsy of the dead birds, in order to look for general alterations that could lead to the death of contact birds.

In conclusion, this is the first report of a natural infection by Paratanaisia spp. in a domiciled bird, here described along with associated histopathological alterations.

All applicable institutional guidelines for the care and use of animals were followed.

\section{Acknowledgements}

This work was supported by the São Paulo Research Foundation - FAPESP (Process n 2015/22851-8).

\section{References}

Abdo W, Sultan K. Histopathological findings of the kidney Trematoda Paratanaisia spp. (Digenea: Eucotylidae) in cattle egret (Bubulcus ibis). Rev Bras Parasitol Vet 2013; 22(2): 312-313. http://dx.doi.org/10.1590/ S1984-29612013000200050. PMid:23856732.

Araújo JLB, Bessa ECA. Moluscos de importância econômica no Brasil. II Subulinidae, Subulina octona (Bruguiére) (Mollusca, Gastropoda, Pulmonata, Stylommatophora). Rev Bras Zool 1993; 10(3): 489-497. http://dx.doi.org/10.1590/S0101-81751993000300016.

Araújo JLB, Keller DG. Moluscos de importância econômica no Brasil. III Subulinidae, Leptinaria unilamellata (Orbigny) (Mollusca, Gastropoda, Pulmonata, Stylommatophora). Rev Bras Zool 1993; 10(3): 499-507. http://dx.doi.org/10.1590/S0101-81751993000300017.

Brandolini SVPB, Amato SB. Desenvolvimento larval de Paratanaisia bragai (Santos) (Digenea, Eucotylidae) sob condiçóes experimentais. Rev 
Bras Zool 2006; 23(4): 1097-1100. http://dx.doi.org/10.1590/S010181752006000400017.

Dumonceaux G, Harrison GJ. Toxins. In: Ritchie BW, Harrison GJ, Harrison LR. Avian medicine: principles and application. Florida: Wingers Publishing, Inc.; 1994. p. 1030-1052.

Gomes DC, Menezes RC, Tortelly R, Pinto RM. Pathology and first occurrence of the kidney trematode Paratanaisia bragai (Santos, 1934) Freitas, 1959 (Digenea: Eucotylidae) in Phasianus colchicus L., 1758, from Brazil. Mem Inst Oswaldo Cruz 2005; 100(3): 285-288. http:// dx.doi.org/10.1590/S0074-02762005000300013. PMid:16113870.

Greiner EC, Ritchie BW. Parasites. In: Ritchie BW, Harrison GJ, Harrison LR. Avian medicine: principles and application. Florida: Wingers Publishing, Inc.; 1994. p. 1007-1029.

Grespan A, Raso TF. Psittaciformes (Araras, Papagaios, Periquitos, Calopsitas e Cacatuas). In: Cubas ZS, Silva JCR, Catão-Dias JL. Tratado de Animais Selvagens: medicina veterinária. 2nd ed. São Paulo: Rocca; 2014. p. 550-589.

Harrison GJ, Ritchie BW. Making distinctions in the physical examination. In: Ritchie BW, Harrison GJ, Harrison LR. Avian medicine: principles and application. Florida: Wingers Publishing, Inc.; 1994. p. 144-175.

Jeckel EA. Técnicas de rotina em histologia. In: Carli GA. Parasitologia clínica: seleção de métodos e técnicas de laboratório para o diagnóstico das parasitoses humanas. 2nd ed. São Paulo: Atheneu; 2007. p. 593-608.

Kanev I, Radev V, Fried B. Family Eucotylidae Cohn, 1904. In: Gibson DI, Jones A, Bray RA. Keys to trematoda. New York: CABI Publishing; 2002. p. 147-152. http://dx.doi.org/10.1079/9780851995472.0147.

Keller DG, Araujo JLB. Ciclo evolutivo de Paratanaisia bragai (Santos, 1934) (Trematoda, Eucotylidae) com novo hospedeiro intermediário no Brasil: Leptinaria unilamellata (D’Orbigny, 1835) (Gastropoda, Pulmonata, Subulinidae) em condições de laboratório. Rev Bras Parasitol Vet 1992; 1(2): 89-92.

Luppi MM, Melo AL, Motta ROC, Malta MCC, Gardiner CH, Santos LR. Granulomatous nephritis in psittacines associated with parasitism by the trematode Paratanaisia spp. Vet Parasitol 2007; 146(3-4): $363-$ 366. http://dx.doi.org/10.1016/j.vetpar.2007.03.011. PMid:17418949.

Mapeli EB, Nascimento AA, Szabó MPJ, Tebaldi JH. Infecçôes naturais por helmintos em perdizes (Rhynchotus rufescens Temminck, 1815) de cativeiro, no município de Jaboticabal, estado de São Paulo. Arq Inst Biol (Sao Paulo) 2003; 70(4): 415-418.
Menezes RC, Mattos DG Jr, Tortelly R, Muniz-Pereira LC, Pinto RM, Gomes DC. Trematodes of free range reared guinea fowls (Numida meleagris Linnaeus, 1758) in the state of Rio de Janeiro, Brazil: Morphology and pathology. Avian Pathol 2001; 30(3): 209-214. http://dx.doi. org/10.1080/03079450124448. PMid:19184902.

Momo C, Garrido E, Werther K. Anatomopathological findings in captive-raised red-winged tinamou (Rhynchotus rufescens). Braz J Vet Res Anim Sci 2016; 53(3): 227-234. http://dx.doi.org/10.11606/issn.16784456.v53i3p227-234.

Pinto RM, Menezes RC, Tortelly R. Systematic and pathologic study of Paratanaisia bragai (Santos, 1934) Freitas, 1959 (Digenea, Eucotylidae) infestation in ruddy ground dove Columbina talpacoti (Temminck, 1811). Arq Bras Med Vet Zootec 2004; 56(4): 472-479. http://dx.doi. org/10.1590/S0102-09352004000400008.

Santi M, André MR, Hoppe EGL, Werther K. Occurrence of Paratanaisia confusa Freitas, 1951 in free-living guira cuckoo (Guira guira, Cuculiformes: Crotophagidae). Rev Bras Parasitol Vet 2017; 26(2): 248-251. http:// dx.doi.org/10.1590/s1984-29612017014. PMid:28746453.

Santi M, André MR, Hoppe EGL, Werther K. Renal trematode infection in wild birds: Histopathological, morphological, and molecular aspects. Parasitol Res 2018; 117(3): 883-891. http://dx.doi.org/10.1007/s00436018-5767-0. PMid:29392392.

Sick H. Ornitologia brasileira. Rio de Janeiro: Nova Fronteira; 1997.

Silva TM, Pavan LF, Guimarães-Okamoto PTC, Milbradt EL, Andreatti RL Fo, Silva RJ, et al. First record of Paratanaisia bragai (Digenea: Eucotylidae) in blue and gold macaw (Ara ararauna). Rev Bras Parasitol Vet 2016; 25(1): 112-115. http://dx.doi.org/10.1590/S1984-29612016001. PMid:26982561.

Tavela AO, Carreta M Jr, Oliveira AR, Carneiro FT, Silva VHD, Braga FR, et al. Parasitism by Paratanaisia bragai (Digenea, Eucotylidae) in commom waxbill (Estrilda astrild). Arq Bras Med Vet Zootec 2014; 66(4). 1276-1280. http://dx.doi.org/10.1590/1678-7136.

Unwin S, Chantrey J, Chatterton J, Aldhoun JA, Littlewood DTJ. Renal trematode infection due to Paratanaisia bragai in zoo housed Columbiformes and a red bird-of-paradise (Paradisaea rubra). Int J Parasitol Parasites Wildl 2012; 2(2): 32-41. http://dx.doi.org/10.1016/j. ijppaw.2012.11.001. PMid:24533313.

Xavier VB, Oliveira-Menezes A, Santos MAJ, Amato SB, Torres EJL, Pinheiro J, et al. Histopathological changes in the kidneys of vertebrate hosts infected naturally and experimentally with Paratanaisia bragai (Trematoda, Digenea). Rev Bras Parasitol Vet 2015; 24(2): 241-246. http:// dx.doi.org/10.1590/S1984-29612015017. PMid:26154968. 